\title{
OPERATING ROOM USE OF HYPERTONIC SOLUTIONS: A CLINICAL REVIEW
}

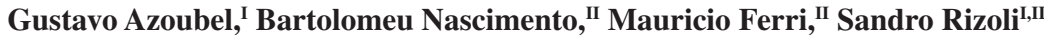

doi: $10.1590 / \mathrm{S} 1807-59322008000600021$

Azoubel G, Nascimento b, Ferri M, Rizoli S. Operating room use of hypertonic solutions: a clinical review. Clinics. 2008;63:833-40.

Hyperosmotic-hyperoncotic solutions have been widely used during prehospital care of trauma patients and have shown positive hemodynamic effects. Recently, there has been a growing interest in intra-operative use of hypertonic solutions. We reviewed 30 clinical studies on the use of hypertonic saline solutions during surgeries, with the majority being cardiac surgeries. Reduced positive fluid balance, increased cardiac index, and decreased systemic vascular resistance were the main beneficial effects of using hypertonic solutions in this population. Well-designed clinical trials are highly needed, particularly in aortic aneurysm repair surgeries, where hypertonic solutions have shown many beneficial effects. Examining the immunomodulatory effects of hypertonic solutions should also be a priority in future studies.

KEYWORDS: Hypertonic solution; Saline solution; Surgery; Perioperative; Randomized control trial.

\section{INTRODUCTION}

Most of the clinical experiences to date on the use of hypertonic saline have come from trauma patients in the prehospital setting or en route to the emergency room..$^{1-3}$ The effects of hyperosmotic-hyperoncotic solutions (HHS) in rapidly restoring hemodynanic stability, boosting cardiac function, and possibly improving outcome, along with a demonstrated safety in trauma population, provide the basis for the growing interest in their perioperative use over the last two decades. The majority of studies were carried out in elderly cardiac surgery patients who were at an increased risk for intraoperative cardiac complications. The main goals of using HHS during the perioperative period are to prevent hypovolemia and to assure adequate tissue oxygenation while avoiding fluid overload. In this review, we included 30 studies $^{4-33}$ of human subjects treated with $7.2-7.5 \% \mathrm{NaCl}$

${ }^{\text {I }}$ Department of Surgery, University of Toronto - Toronto, Canada. II Department of Trauma and Critical Care, Sunnybrook Health Sciences Centre - Toronto, Ontario, Canada.

Email: gustavo.azoubel@utoronto.ca / guga_azoubel@yahoo.com Tel.: 4165194041

Received for publication on July 11, 2008

Accepted for publication on August 4, 2008 alone (Hypertonic Saline - HS), $\mathrm{NaCl}$ with dextran (HSD) or $\mathrm{NaCl}$ with hetastarch (HSS). In 15 cases, the fluids were administered during cardiac surgeries (table 1). Seven cases involved patients undergoing aortic aneurysm repair (table 2 ), two cases involved providing tested hypertonic saline in neurosurgical patients (table 3), two cases involved patients undergoing abdominal hysterectomy (table 4), and four cases involved patients who underwent minor operations (table 5). Seven studies ${ }^{34-40}$ tested the hypertonic saline using tonicity levels other than those examined previously (ranging from $1.8 \%$ to $5.85 \% \mathrm{NaCl}$ ) and were among the first reported clinical trials on the perioperative use of HS. ${ }^{34}$ Two studies ${ }^{41,42}$ had no control groups, and these studies were thus excluded from this review.

\section{CARDIAC SURGERY}

With the exception of two studies (involving patients undergoing cardiac valve surgery) from the group of cardiac surgeries, ${ }^{22,31}$ all clinical experiences were derived from coronary artery bypass grafting $(\mathrm{CABG})$ patients. Amongst all patients undergoing cardiac surgery, the most relevant finding was the substantial decrease in positive fluid balance. By titrating volume infusion against pulmonary capillary 
wedge pressure (PCWP), Oliveira et al. ${ }^{16}$ while studying the effect of HSD in the hemodynamic status of cardiac patients, demonstrated an enormous positive fluid balance in the control group compared to the HSD group. HSD was being tested in regards to it's effect in the hemodynamic status and volume of fluid administrated. The Ringer's solution group required almost $4000 \mathrm{ml}$ more positive fluid balance than the control group to arrive at the same hemodynamic status. A near zero balance was seen in the HSD group 48 hours after surgery. The Tollofsrud study ${ }^{20}$ also reported a relevant 1200 $\mathrm{ml}$ cumulative spare volume in HHS patients using a $4 \mathrm{ml} /$ $\mathrm{kg}$ of body weight fixed dose. Even when the HHS-treated group was compared to the control group, which used colloid solutions, administering hypertonic solution was deemed to be advantageous. ${ }^{6,7}$ Furthermore, preoperative hemodilution with HHS in patients with normal left ventricular ejection fraction who underwent $\mathrm{CABG}$ was recently reported to decrease the need for perioperative fluid independent of the type of mixed colloid used. ${ }^{30}$ Recently, in a study involving 50 patients undergoing cardiac valve surgery, Bueno and colleagues31 administered $4 \mathrm{ml} / \mathrm{kg}$ of HHS before cardiopulmonary bypass with a fluid balance of near zero during the first 48 hours as compared to a large positive balance in the Ringer's group. Finally, three studies by Jarvela and colleagues ${ }^{25,26,28}$ stated that administering a single dose of $4 \mathrm{ml} / \mathrm{kg}$ of $7.5 \% \mathrm{NaCl}$ over 30 minutes to $\mathrm{CABG}$ patients during the postoperative rewarming phase resulted in intense diuretic effects and decreased fluid retention. Excess body fluids that had accumulated during cardiopulmonary bypass and cardiac surgery were excreted because of the increased diuresis in these studies. In one study, ${ }^{28}$ weight gain in the NS - $0.9 \%$ Saline control group was significantly greater than that in the HS group during the first postoperative day $(1.9 \pm 1.4 \mathrm{~kg}$, median, $2.1 \mathrm{~kg}$ and $0.8 \pm$ $1.5 \mathrm{~kg}$, median, $0.8 \mathrm{~kg}$, respectively; $\mathrm{p}=0.005$ ). This result corroborated observations of decreased fluid retention.

Cardiac index (CI) was another hemodynamic endpoint that was favourably altered by hypertonic saline in the majority of the studies and was independent of whether the solution infusion was titrated. Studies that titrated the same infusion as controls showed a substantial increase in left ventricular filling pressure. ${ }^{7,16,20}$ In two studies ${ }^{8,31}$ that used a fixed dose, the beneficial effect of increasing the CI lasted well into the $48 \mathrm{~h}$ after surgery. However, by administering a single $250 \mathrm{ml}$ postoperative dose of HHS and HSD, Sirieix et al. ${ }^{22}$ verified a transient increase in CI that returned to baseline values within 3 hours despite significant increases in left ventricular preload and left ventricular ejection fraction in their patients. Also, the hemodynamic effects of HS lasted only about 1 hour in the Jarvela study. ${ }^{25}$ However, the preoperative hemodilution with HSD and HSS in the Molter study ${ }^{30}$ significantly augmented
CI. Another important effect of administrating hypertonic solutions throughout these studies was the reduction in systemic vascular resistance. Three studies $^{8,22,31}$ reported a reduction in pulmonary vascular resistance after infusion of HSS or HSD. Regarding mean arterial pressure (MAP), most authors observed either a transient increase or no significant difference in MAP compared to controls when hypertonic solutions were infused. Nevertheless, two studies required further attention. In the Prien study, ${ }^{11}$ a transient drop in MAP was documented after infusion of a fixed dose of $250 \mathrm{ml} \mathrm{HSS}$ over 15 minutes. The $20 \%$ decrease in MAP from baseline was seen in the first 5 minutes of the infusion and was followed by hypervolemic left ventricular failure in the majority of these patients. By applying the same rate of infusion, Sirieix and colleagues ${ }^{22}$ managed the severe hypotension that developed after hypertonic solution administration in three of 16 patients. However, they observed significant augmentation of MAP following hypertonic solution infusion in the majority of their patients compared to those given a control solution. These patients also reported significant increase in central venous pressure (CVP) following infusion of a hypertonic solution.

In general, the pulmonary function was positively affected throughout the studies. There was a statistically significant drop in $\mathrm{PaO}_{2}$ in the control groups, while $\mathrm{PaO}_{2}$ remained more constant in HSS treated patients.8 Bueno et al.31 reported that patients who underwent cardiopulmonary bypass maintained a significantly higher $\mathrm{PaO}_{2} / \mathrm{FiO}_{2}$ ratio after HSD infusion compared to those given Ringer's solution. Molter et al. ${ }^{30}$ described a relevant higher $\mathrm{O}_{2}$ delivery index in the hypertonic solution treated group. Furthermore, two additional studies demonstrated earlier extubation times after hypertonic saline administration. ${ }^{19,31}$

Hypernatremia was a common finding after using HHS in cardiac surgery. However, no neurological symptoms were associated with the increased sodium load, even when serum sodium reached concentrations of over $160 \mathrm{mmol} / \mathrm{L} .{ }^{31}$

\section{AORTIC ANEURYSM SURGERY}

Since the first reported study in 1987 on the use of hypertonic saline $(7.2-7.5 \% \mathrm{NaCl})$ in patients who underwent surgical repair of abdominal aortic aneurysm, a total of 91 such patients have been treated with hypertonic solutions to date. Most of the studies gave HS mixed with hydroxyetilhyl starch and had HES as the control solution (table 2). The most striking result was the reduced need for fluid intake in patients receiving HHS. First, Auler et al.4 assessed HS in three abdominal aortic aneurysm AAA patients and found a decreased need for perioperative fluid despite a slightly greater blood loss in this group in relation 
Table 1 - Perioperative studies on the use of hypertonic saline $(7.2-7.5 \% \mathrm{NaCl})$ alone or in association with either dextran (HSD) or hydroxielthyl starch (HSS) compared to hydroxiethyl starch (HES), Ringer's solution (RL), normal saline (NS), NS-HSD or polygeline during cardiac surgery

\begin{tabular}{|c|c|c|c|c|}
\hline Study by year & Solution Dose & Control Solution & $\mathrm{n}$ (solution) & $\mathrm{n}$ (control) \\
\hline Boldt et al. ${ }^{6} 1990$ & $\mathrm{HSS} 4.5 \mathrm{ml} / \mathrm{Kg}$ & HES & 10 & 20 \\
\hline Boldt et al. ${ }^{7} 1991$ & $\mathrm{HSS} 2.7 \mathrm{ml} / \mathrm{Kg}$ & HES & 15 & 30 \\
\hline Boldt et al. ${ }^{8} 1991$ & $\mathrm{HSS} 3.1 \mathrm{ml} / \mathrm{Kg}$ & HES & 15 & 15 \\
\hline Boldt et al..$^{9} 1991$ & $\mathrm{HSS} 3.8 \mathrm{ml} / \mathrm{Kg}$ & HES & 15 & 30 \\
\hline Auler et al. ${ }^{10} 1992$ & HS $4 \mathrm{ml} / \mathrm{kg}$ & NS & 10 & 11 \\
\hline Prien et al. ${ }^{11} 1993$ & $\mathrm{HSS} 3.5 \mathrm{ml} / \mathrm{kg}$ & HES & 18 & 19 \\
\hline Oliveira et al. ${ }^{16} 1995$ & HSD $235 \mathrm{ml}$ & RL & 10 & 10 \\
\hline Mazhar et al. ${ }^{19} 1998$ & $\mathrm{HS} 5 \mathrm{ml} / \mathrm{kg}$ & Polygeline & 10 & 10 \\
\hline Tollofsrud et al. ${ }^{20} 1998$ & $\mathrm{HSD} 4 \mathrm{ml} / \mathrm{kg}$ & $\mathrm{RL}$ & 10 & 10 \\
\hline Sirieix et al. ${ }^{22} 1999$ & HSD/HSS 250ml & HES & 16 & 8 \\
\hline Jarvela et al. ${ }^{25} 2001$ & $\mathrm{HS} 4 \mathrm{ml} / \mathrm{kg}$ & NS & 20 & 20 \\
\hline Jarvela et al. ${ }^{26} 20011632$ & $\mathrm{HS} 4 \mathrm{ml} / \mathrm{kg}$ & NS/HES & 16 & 32 \\
\hline Jarvela et al. ${ }^{28} 2002$ & HS $4 \mathrm{ml} / \mathrm{kg}$ & NS & 36 & 36 \\
\hline Molter et al. ${ }^{30} 2003$ & HSD/HSS $150 \mathrm{ml}$ & NS/NS-HES/NS-HSD & 16 & 27 \\
\hline Bueno et al. ${ }^{31} 2004$ RL 2525 & $\mathrm{HSD} 4 \mathrm{ml} / \mathrm{kg}$ & RL & 25 & 25 \\
\hline Total & & & 242 & 303 \\
\hline
\end{tabular}

Table 2 - Perioperative studies on the use of hypertonic saline $(7.2-7.5 \% \mathrm{NaCl})$ alone or in association with either dextran (HSD) or hydroxielthyl starch (HSS) compared to hydroxiethyl starch (HES), Ringer's solution (RL)/6\% Dextran70, or normal saline (NS) in aortic aneurysm surgery

\begin{tabular}{|c|c|c|c|c|}
\hline Study by Year & Solution Dose & Control Solution & $\mathrm{n}$ (solution) & $\mathrm{n}$ (control) \\
\hline Auler et al. ${ }^{4} 1987$ & $\mathrm{HS} 4 \mathrm{ml} / \mathrm{kg}$ & NS & 5 & 5 \\
\hline Younes et al..$^{5} 1988$ & HS 4 ml/kg & NS & 18 & 13 \\
\hline Javanovic et al. ${ }^{12} 1995$ & HSD 4-5 ml/kg & RL/6\%Dextran70 & 9 & 19 \\
\hline Albrecht et al. ${ }^{13} 1995$ & HSS $214 \mathrm{ml}$ & HES & 11 & 12 \\
\hline Ellinger et al. ${ }^{14} 1995$ & HSS $2.4 \mathrm{ml} / \mathrm{kg}$ & HES & 20 & 20 \\
\hline Christ et al. ${ }^{17} 1997$ & HSD/HSS $3.3 \mathrm{ml} / \mathrm{kg}$ & HES & 12 & 10 \\
\hline Ragaller et al. ${ }^{23} 2000$ & HSS $162 \mathrm{ml}$ & HES & 16 & 16 \\
\hline Totals & & & 91 & 95 \\
\hline
\end{tabular}

to the NS group. More remarkable results were seen in two other studies. By preoperatively titrating a bolus of $50 \mathrm{ml}$ of HSS to the endpoint of the highest CI at lowest PCWP in high risk patients, Ellinger and colleagues ${ }^{14}$ demonstrated an average four-fold decrease in the need for fluid in these patients as compared to those in the control group, who were given HES. In the Christ study, ${ }^{17}$ a fixed dose of $250 \mathrm{ml} \mathrm{HHS}$ was applied during aortic clamping for over 20 minutes and resulted in a significantly reduced fluid balance compared to the HES-treated control group ( $2471 \pm 949 \mathrm{ml}$ versus 3387 $\pm 1248 \mathrm{ml}$ ). Additional Ringer's solution was administrated in both groups to achieve defined PCWP. Recently, another study that titrated dose against the best PCWP/CI ratio infused the HSS solution after aortic clamping and reported less fluid retention compared to those given an HES solution (mean $162 \pm 111 \mathrm{ml}$ versus mean $265 \pm 108 \mathrm{ml}$ ). ${ }^{23}$ Other important effects of HHS on hemodynamic variables were also reported. In the Ellinger study, ${ }^{14}$ the CI nearly doubled in patients treated with HSS in a titrated fashion compared to that in patients treated with HES.

Other studies have also demonstrated increased CIs.,17 In addition, a decrease in systemic vascular resistance index was reported immediately after the infusion of HS4 and after administration of HHS during aortic cross-clamping. ${ }^{17}$ Auler 
et al. ${ }^{4}$ also stated that pulmonary vascular resistance soon decreased after HS administration.

No hypotension developed in patients receiving HHS, regardless of whether the infusion was titrated; ${ }^{14,17}$ the sodium load increased, but no related symptoms were reported. ${ }^{17}$ One anaphylactoid reaction occurred and was attributed to HES use. ${ }^{17}$ One patient died in the Ragaller study, ${ }^{23}$ though it was unclear which group the patient belonged to. Three more patients developed serious complications in that study, but they were reported to be unrelated to fluid therapy.

\section{NEUROSURGERY}

Only two intraoperative studies involving neurosurgical patients were assessed for this review. While two other studies have been published, these two were excluded due to both a lack of controls ${ }^{41}$ and the utilization of $3 \% \mathrm{NaCl}$ solution rather than 7.2-7.5\% NaCl solution. ${ }^{39}$ Hemodynamic parameters did not change when HS was used as opposed to $20 \%$ mannitol in the two excluded studies. Gemma el al18 found no difference in brain bulk and cerebrospinal fluid (CSF) during elective procedures between infusion of a fixed dose of $2.5 \mathrm{ml} / \mathrm{kg}$ HS and administration of $2.5 \mathrm{ml} /$ $\mathrm{kg}$ of mannitol. Erard and colleagues ${ }^{29}$ reported that a single infusion of solutions of equal osmolarity, $\mathrm{NaCl} 7.5 \%$ or mannitol $20 \%$, induced a similar osmolar variation over time in both hypertonic groups.

\section{ABDOMINAL HYSTERECTOMY}

Recently, Kolsen-Petersen and colleagues ${ }^{32,33}$ published two studies on the use of HS in abdominal surgery. Based on previous studies in human blood cell cultures ${ }^{43-45}$ and different animals models ${ }^{43,46}$ that reported that hypertonicity is permissive for lymphocyte proliferation ${ }^{43}$ and restrictive for neutrophil function, ${ }^{45,46-50}$ the researchers observed the immunological effects of a fixed dose of HS on postoperative women who underwent abdominal hysterectomy. Their first randomized double-blind study ${ }^{32}$ involved 62 women who received either $4 \mathrm{ml} / \mathrm{kg}$ of $7.5 \%$ or $32 \mathrm{ml} / \mathrm{kg}$ of $0.9 \%$ $\mathrm{NaCl}$ over $20 \mathrm{~min}$. The study found that an infusion of HS saline did not alter the postoperative immune response after abdominal hysterectomy. In the subsequent clinical trial also by Kolsen-Peterson el al., ${ }^{33}$ modest changes from HS infusion were observed when compared to normal saline treated patients. These changes included a temporary increase in the number of B cells in the peripheral blood $(\mathrm{p}<0.01)$, an augmentation in the concentration of plasma elastase $(\mathrm{p}<0.05)$, and a decrease in the number of circulating neutrophils $(\mathrm{p}<0.001)$.

\section{MINOR SURGERIES/HS FOR PRELOADING BEFORE SPINAL ANAESTHESIA}

In a 1995 study demonstrating the inotropic effects of HS in anesthetised patients without cardiovascular disease, Goertz et al. ${ }^{15}$ concluded that the apparent improvement of left ventricular systolic function in response to hypertonic saline/hetastarch was caused mainly by the combined effects of increased left ventricular preload and reduced left ventricular afterload. Three studies ${ }^{21,24,27}$ focused on the use of HS for preloading before spinal anaesthesia. Two of these studies, conducted by Jarvela and colleagues, ${ }^{24,27}$ found no significant differences regarding hemodynamic parameters and sodium load when the HS-infused group

Table 3 - Perioperative studies on the use of hypertonic saline $(7.2-7.5 \% \mathrm{NaCl})$ alone or in association with either dextran (HSD) or hydroxielthyl starch (HSS) compared to $20 \%$ mannitol or normal saline (NS) in neurosurgery

\begin{tabular}{|c|c|c|c|c|}
\hline Study by Year & Solution dose & Control Solution & $\mathrm{n}$ (solution) & $\mathrm{n}$ (control) \\
\hline Gemma et al. ${ }^{18} 1997$ & HS $2.5 \mathrm{ml} / \mathrm{kg}$ & Mannitol & 25 & 25 \\
\hline Erard et al. ${ }^{29} 2003$ & HS 4.95 mOsmkg(-1) & Mannitol & 10 & 20 \\
\hline Totals & & & 35 & 45 \\
\hline
\end{tabular}

Table 4 - Perioperative studies on the use of hypertonic saline (7.2-7.5\% NaCl) compared to normal saline (NS) in abdominal hysterectomy

\begin{tabular}{lccc}
\hline Study by Year & Solution dose & Control & n (solution) \\
\hline Kolsen-Petersen et al. ${ }^{32} 2004$ & HS $4 \mathrm{ml} / \mathrm{kg}$ & $\mathrm{NS}$ & 21 \\
Kolsen-Petersen et al. ${ }^{33} 2004$ & HS $4 \mathrm{ml} / \mathrm{kg}$ & $\mathrm{NS}$ & 10 \\
\hline Totals & & & 31 \\
\hline
\end{tabular}


Table 5 - Perioperative studies on the use of hypertonic saline 7.2-7.5\% NaCl) alone or in association with hydroxielthyl starch (HSS) compared to hydroxiethyl starch (HES) or normal saline (NS) in minor surgeries and before spinal anaesthesia

\begin{tabular}{|c|c|c|c|c|}
\hline Study by Year & Solution dose & Control & $\mathrm{n}$ (solution) & $\mathrm{n}$ (control) \\
\hline Goertz et al. ${ }^{15} 1995$ & $\mathrm{HSS} 4 \mathrm{ml} / \mathrm{kg}$ & HES & 13 & 13 \\
\hline Durasnel et al. ${ }^{21} 1999$ & $\mathrm{HS} \pm 1.5 \mathrm{ml} / \mathrm{kg}$ & NS & 24 & 24 \\
\hline Jarvela et al. ${ }^{24} 2000$ & HS $1.6 \mathrm{ml} / \mathrm{kg}$ & NS & 20 & 20 \\
\hline Jarvela et al. ${ }^{27} 2001$ & HS $1.6 \mathrm{ml} / \mathrm{kg}$ & NS & 20 & 20 \\
\hline Totals & & & 77 & 77 \\
\hline
\end{tabular}

was compared to the control group. However, in a separate study by Durasnel et al., ${ }^{21}$ infusion of $100 \mathrm{ml}$ of HS for over 15 minutes prior to spinal anaesthesia effectively prevented the occurrence of hypotension when directly compared to patients infused with normal saline. Hypotension occurred in two of 24 patients in the HS group and eight of 24 in the NS group $(\mathrm{p}<0.05)$.

\section{COMMENTS}

The improved fluid balance seen in HHS-treated patients seems to be the result of various mechanisms. First, after the stress and shock of surgery, cells may become edematous. ${ }^{51}$ As a result, HHS rapidly shifts fluid from the intracellular compartment to the intravascular space with consequent plasma expansion. ${ }^{52}$ HSS increases renal blood flow and glomerular filtration rate, induces renal vasodilatation, ${ }^{53}$ and decreases plasma aldosterone levels, all resulting in increased urine output. ${ }^{54}$ An immediate increase in urine output following HHS administration was observed in several cardiac studies. ${ }^{25,26,28,31}$ In the setting of CPB, extracorporeal circulation is particularly related to the release of cytokines, vasoactive mediators, hormones and autacoids that may cause endothelium damage, increased vascular permeability, tissue oedema, and vasoconstriction. Thus, fluid accumulation is an expected event during CPB due to increased extracellular fluid and intracellular oedema. In addition to the fluid shift from erythrocytes and endothelial cells, HHS may attenuate the inflammatory response, leading to less capillary leakage. In five studies, ${ }^{6-8,16,31}$ the use of hypertonic solution before CPB may have led to a better inflammatory profile and accounted for the favourable fluid balance. Moreover, hypertonic infusions resulted in increased plasma protein ${ }^{55}$ and decreased protein loss from the intravascular space, which may further have positives effects on fluid balance. However, analysis of serum protein was not the main concern in these studies.

While volume expansion and reduced afterload have been accepted as an explanation for the increased CI, the direct effects of hypertonic solutions on cardiac contractility remain controversial. Most recent results indicated that at least a slight effect may exist. ${ }^{56-58}$ The remarkable increase in CI seen in the Ellinger study, ${ }^{14}$ where HSS was titrated to the highest $\mathrm{CI}$ at lowest PCWP and suggested that hypertonic saline may improve cardiac performance. Only one study presented data conflicting with this hypothesis: transient hypervolomic left ventricular heart failure was induced by a 15-minute infusion of HHS in the Prien study. ${ }^{11}$ This rapid HHS infusion rate could be accountable for the transient fluid overload seen in their patients. Moreover, severe hypotension occurred after a similar rate of administration in the Siriex study. ${ }^{22}$ It is thus generally believed that the degree of hypotension is dependent upon the rate of infusion..$^{59}$ Therefore, a longer rate of infusion appears to be appropriate for intraoperative purposes.

Numerous reports of reductions in systemic vascular resistance index as well as a few reports of decreased pulmonary vascular resistance following HHS administration were all consistent with the existing established model. ${ }^{60-62}$

The most transient hemodynamic effects seen in the Javerla studie ${ }^{25-27}$ could be explained by the strong diuretic effects observed immediately after infusion of HS.

The decrease in volume overload along with the improved microcirculation and the decreased interstitial oedema may be responsible for the more efficient pulmonary function observed in several studies. ${ }^{8,20,31}$ Large volume resuscitation with crystalloids worsened lung oedema and prolonged the need for mechanical ventilation. ${ }^{63-65}$ Christ et al. ${ }^{17}$ has suggested that less fluid excess accompanied by decreased oedema formation is particularly beneficial for high risk patients.

Three studies have shown that a titrated dose was the preferred method of administrating hypertonic solution in a perioperative setting. The Prien study 11 reported a case of left ventricular fluid overload caused by a fixed dose of 3-4 ml/kg over 15 minutes. Ellinger et al. ${ }^{14}$ titrated the infusion in patients undergoing aortic aneurysm surgery and found that a fixed dosage of $4 \mathrm{ml} / \mathrm{kg}$ was too high for atrisk cardiac patients with slight hypovolemia. Furthermore, severe hypotension developed after the infusion of a 
fixed $250 \mathrm{ml}$ dose given over 15 minutes in patients who underwent cardiac valve repair in the Sirieix study. ${ }^{22}$ Titrated infusion gained further support from animal studies. Pascual et al. ${ }^{55}$ administered titrated doses of HSD in a swine model of intra-operative hemorrhagia and found greater volume expansion effect of the solution in hypovolemic conditions. Furthermore, Nguyen et al. ${ }^{66}$ reported the advantages of titrated resuscitation in haemorrhaged adult sheep. Thus, the use of titrated HHS infusion in this population seems to be more appropriate.

However, it is clear that certain limitations exist in isolated studies of aortic aneurysm repair. First, these studies included a small number of patients with little synchronization. None of the studies involved more than 20 patients in the tested groups, which limited the power of the statistical analysis. There were also many different deficiencies in the study designs and methodologies. Auler et al. ${ }^{4}$ performed a non-randomised study and included patients with thoracoabdominal and abdominal aneurysm in the experimental group. Furthermore, the studies were not blind. Albrecht and colleagues ${ }^{13}$ examined patients before surgery and during the induction of anaesthesia. In the Ragaller study, ${ }^{23}$ the staff was not blinded, which increased the possibility of bias once the parameters were defined. Furthermore, the studies assessed only a limited number of outcome measures. None of the clinical studies considered the immunomodulatory effects of hypertonic saline. Consistent with the 2002 Cochrane group review ${ }^{67}$ on the use of intravenous fluids (non-blood fluids) for abdominal aortic surgery, we also found no overwhelming evidence to support or reject the preferential use of any particular type of fluid.

For neurosurgical patients, however, the current shortage of studies precluded drawing any conclusions. The lower utilization of HS in neurosurgery may be the result of a lack of studies as well as study parameters on the safety and beneficial effects of using HS. ${ }^{18,29}$ Despite the similarity of the HS dose used by three studies for preloading before spinal anaesthesia, ${ }^{21,24,27}$ only one group reported that infusion of the solution was capable of preventing hypotension. ${ }^{21}$ These studies used low HS doses, while most clinical trials that reported positive effects from HS used higher doses.

The discrepancy between the modest findings reported by Kolsen-Petersen et al. ${ }^{32,33}$ and the results from previous studies on the immunomodulatory properties of HS may be due to the small number of patients and the characteristics of the studied population. Kolsen-Petersen et al. studied healthy normovolemic women who underwent a standardized surgical procedure. The immunologic response to trauma depended heavily on the amount of tissue injury ${ }^{68}$ and blood loss. ${ }^{69}$ Ischemic reperfusion injury seen in abdominal aortic aneurysm repair is another important cause of inflammatory response. ${ }^{70}$ However, as mentioned earlier, CPB during cardiac surgery was also associated with further inflammation. Based on these results, patients undergoing aortic aneurysm repair (particularly ruptured aortic aneurysm repair) appear to be the population that experiences the most beneficial effects from hypertonic solutions.

The use of colloids along with hypertonic saline prolongs volume expansion and may also positively influence cardiac function. However, colloids are also linked to a small but significant number of complications, particularly anaphylactic reactions and changes in coagulation function. An anaphylactic reaction in one patient was attributed to HES use in the Christ study. ${ }^{17}$ In two other studies, ${ }^{16,20}$ drainages from the chest were slightly greater in the HSD groups, but the difference was not statistically significant.

\section{CONCLUSION}

Our analysis of 30 published clinical studies on the perioperative use of hypertonic saline (7.2-7.5\% $\mathrm{NaCl}$ ) solutions has shown that administration of the hypertonic solution resulted in beneficial hemodynamic effects, particularly during cardiac surgery. The previously observed reductions in positive fluid balance, increases in CI and decreases in systemic vascular resistance further supported our recommendation of HS use during surgery. Furthermore, our study further indicated that dose administration should be titrated and that the rate of infusion should be slow. This review also demonstrated the urgent need for well-designed randomized clinical trials, particularly in the setting of aortic aneurysm repair, where HS has shown many beneficial effects. The immunomodulatory effects of HS should also be a priority in future studies.

\section{REFERENCES}

1. Mattox KL, Maningas PA, Moore EE, Mateer JR, Marx JA, Aprahamian $\mathrm{C}$, et al. Prehospital hypertonic saline/dextran infusion for post-traumatic hypotension. The U.S.A. Multicenter Trial. Ann Surg. 1991;213:48291.
2. Younes RN, Aun F, Accioly CQ, Casale LP, Szajnbok I, Birolini D. Hypertonic solutions in the treatment of hypovolemic shock: a prospective, randomized study in patients admitted to the emergency room. Surgery. 1992;111:380-5. 
3. Vassar MJ, Perry CA, Holcroft JW.Prehospital resuscitation of hypotensive trauma patients with $7.5 \% \mathrm{NaCl}$ versus $7.5 \% \mathrm{NaCl}$ with added dextran: a controlled trial. J Trauma. 1993;34:622-32; discussion $632-3$.

4. Auler JO Jr, Pereira MH, Gomide-Amaral RV, Stolf NG, Jatene AD, Rocha e Silva M. Hemodynamic effects of hypertonic sodium chloride during surgical treatment of aortic aneurysms. Surgery. 1987;101:594601.

5. Younes RN, Bechara MJ, Langer B, Aun F, Birolini D, Kuznieck S, et al. [Use of a hypertonic solution of $7.5 \% \mathrm{NaCl}$ in preventing postdeclamping hypotension of the abdominal aorta]AMB Rev Assoc Med Bras. 1988;34:150-4

6. Boldt J, Kling D, Herold C, Dapper F, Hempelmann G. Volume therapy with hypertonic saline hydroxyethyl starch solution in cardiac surgery. Anaesthesia. 1990;45:928-34.

7. Boldt J, Kling D, Weidler B, Zickmann B, Herold C, Dapper F, et al. Acute preoperative hemodilution in cardiac surgery: volume replacement with a hypertonic saline-hydroxyethyl starch solution. J Cardiothorac Vasc Anesth. 1991;5:23-8.

8. Boldt J, Zickmann B, Ballesteros M, Herold C, Dapper F, Hempelmann G. Cardiorespiratory responses to hypertonic saline solution in cardiac operations. Ann Thorac Surg. 1991;51:610-5.

9. Boldt J, Zickmann B, Herold C, Ballesteros M, Dapper F, Hempelmann $\mathrm{G}$. Influence of hypertonic volume replacement on the microcirculation in cardiac surgery.Br J Anaesth. 1991;67:595-602.

10. Auler JO Jr, Zin WA, Martins MA, Younes RN, Negri EM, Hoelz C, et al. Respiratory system mechanics in patients treated with isotonic or hypertonic NaCl solutions.Circ Shock. 1992;36:243-8.

11. Prien T, Thulig B, Wusten R, Schoofs J, Weyand M, Lawin P. [Hypertonic-hyperoncotic volume replacement $(7.5 \% \mathrm{NaCl} / 10 \%$ hydroxyethyl starch $200.000 / 0.5$ ) in patients with coronary artery stenoses]Zentralbl Chir. 1993;118:257-63; discussion 264-6.

12. Javanovic K, Marenovic T, Filipovic N, Krivokapic B, Smiljanic B, Mancic D. [Use of a $7.5 \% \mathrm{NaCl} / 6 \%$ Dextran 70 solution in the prevention of hemodynamic disorders during surgery of abdominal aortic aneurysms]Vojnosanit Pregl. 1995;52:34-8.

13. Albrecht MD, Schroth M, Fahnle M, Ellinger K.Effects of hypertonichyperoncotic infusion on the human atrial natriuretic factor in a standardized clinical trial. Shock. 1995;3:152-6.

14. Ellinger K, Fahnle M, Schroth M, Albrecht DM. Optimal preoperative titrated dosage of hypertonic-hyperoncotic solutions in cardiac risk patients. Shock. 1995;3:167-72.

15. Goertz AW, Mehl T, Lindner KH, Rockemann MG, Schirmer U, Schwilk B, et al. Effect of $7.2 \%$ hypertonic saline/6\% hetastarch on left ventricular contractility in anesthetized humans. Anesthesiology. 1995;82:1389-95.

16. Oliveira SA, Bueno RM, Souza JM, Senra DF, Rocha-e-Silva M. Effects of hypertonic saline dextran on the postoperative evolution of Jehovah's Witness patients submitted to cardiac surgery with cardiopulmonary bypass. Shock. 1995;3:391-4.

17. Christ F, Niklas M, Kreimeier U, Lauterjung L, Peter K, Messmer K. Hyperosmotic-hyperoncotic solutions during abdominal aortic aneurysm (AAA) resection. Acta Anaesthesiol Scand. 1997;41(1 Pt 1):62-70.

18. Gemma M, Cozzi S, Tommasino C, Mungo M, Calvi MR, Cipriani A, et al. $7.5 \%$ hypertonic saline versus $20 \%$ mannitol during elective neurosurgical supratentorial procedures. J Neurosurg Anesthesiol. 1997:9:329-34
19. Mazhar R, Samenesco A, Royston D, Rees A. Cardiopulmonary effects of $7.2 \%$ saline solution compared with gelatin infusion in the early postoperative period after coronary artery bypass grafting. J Thorac Cardiovasc Surg. 1998;115:178-89.

20. Tollofsrud S, Noddeland H. Hypertonic saline and dextran after coronary artery surgery mobilizes fluid excess and improves cardiorespiratory functions. Acta Anaesthesiol Scand. 1998;42:154-61.

21. Durasnel P, Cresci L, Madougou M, Idrissa A, Cheriff I, Falandry L, et al. [Practice of spinal anesthesia in a developing country: usefulness of vascular preloading with a $7.5 \%$ hypertonic saline solution]Ann $\mathrm{Fr}$ Anesth Reanim. 1999;18:631-5.

22. Sirieix D, Hongnat JM, Delayance S, D'Attellis N, Vicaut E, Berrebi A, et al. Comparison of the acute hemodynamic effects of hypertonic or colloid infusions immediately after mitral valve repair. Crit Care Med. 1999;27:2159-65

23. Ragaller M, Muller M, Bleyl JU, Strecker A, Segiet TW, Ellinger K, et al. Hemodynamic effects of hypertonic hydroxyethyl starch $6 \%$ solution and isotonic hydroxyethyl starch $6 \%$ solution after declamping during abdominal aortic aneurysm repair. Shock. 2000;13:367-73.

24. Jarvela K, Honkonen SE, Jarvela T, Koobi T, Kaukinen S. The comparison of hypertonic saline $(7.5 \%)$ and normal saline $(0.9 \%)$ for initial fluid administration before spinal anesthesia. Anesth Analg. 2000;91:1461-5.

25. Jarvela K, Kaukinen S. Hypertonic saline (7.5\%) after coronary artery bypass grafting. Eur J Anaesthesiol. 2001;18:100-7.

26. Jarvela K, Koskinen M, Kaukinen S, Koobi T. Effects of hypertonic saline $(7.5 \%)$ on extracellular fluid volumes compared with norma saline $(0.9 \%)$ and $6 \%$ hydroxyethyl starch after aortocoronary bypass graft surgery. J Cardiothorac Vasc Anesth. 2001;15:210-5.

27. Jarvela K, Koobi T, Kauppinen P, Kaukinen S. Effects of hypertonic $75 \mathrm{mg} / \mathrm{ml}(7.5 \%)$ saline on extracellular water volume when used for preloading before spinal anaesthesia. Acta Anaesthesiol Scand. 2001;45:776-81.

28. Jarvela K, Kaukinen S. Hypertonic saline (7.5\%) decreases perioperative weight gain following cardiac surgery. J Cardiothorac Vasc Anesth. 2002;16:43-6.

29. Erard AC, Walder B, Ravussin P. [Effects of equiosmolar load of $20 \%$ mannitol, $7.5 \%$ saline and $0.9 \%$ saline on plasma osmolarity, haemodynamics and plasma concentrations of electrolytes]Ann $\mathrm{Fr}$ Anesth Reanim. 2003;22:18-24.

30. Molter GP, Soltesz S, Larsen R, Baumann-Noss S, Biedler A, Silomon M. [Haemodynamic effects following preoperative hypervolemic haemodilution with hypertonic hyperoncotic colloid solutions in coronary artery bypass graft surgery]Anaesthesist. 2003;52:905-18

31. Bueno R, Resende AC, Melo R, Neto VA, Stolf NA. Effects of hypertonic saline-dextran solution in cardiac valve surgery with cardiopulmonary bypass. Ann Thorac Surg. 2004;77:604-11; discussion 611.

32. Kolsen-Petersen JA, Nielsen JO, Tonnesen EM. Effect of hypertonic saline infusion on postoperative cellular immune function: a randomized controlled clinical trial. Anesthesiology. 2004;100:1108-18.

33. Kolsen-Petersen JA, Nielsen JO, Bendtzen K, Tonnesen E. Infusion of hypertonic saline $(7.5 \% \mathrm{NaCl})$ causes minor immunological changes in normovolaemic women. Acta Anaesthesiol Scand. 2004;48:224-33.

34. Shackford SR, Sise MJ, Fridlund PH, Rowley WR, Peters RM, Virgilio RW, et al. Hypertonic sodium lactate versus lactated ringer's solution for intravenous fluid therapy in operations on the abdominal aorta. Surgery. $1983 ; 94: 41-51$ 
35. Cross JS, Gruber DP, Burchard KW, Singh AK, Moran JM, Gann DS. Hypertonic saline fluid therapy following surgery: a prospective study. J Trauma. 1989;29:817-25; discussion 825-6.

36. Croft D, Dion YM, Dumont M, Langlois D.Cardiac compliance and effects of hypertonic saline. Can J Surg. 1992;35:139-44.

37. Baraka A, Taha S, Ghabach M, Sibaii A, Nader A, Matta M. Hypertonic saline prehydration in patients undergoing transurethral resection of the prostate under spinal anaesthesia.Br J Anaesth. 1994;72:227-8.

38. Wang BW, Chiou YH, Chen WB, Peng TY, Leung HK. Intravenous pretreatment of hypertonic saline can prevent systemic hypotension induced by spinal anesthesia. Acta Anaesthesiol Sin. 1997;35:85-90.

39. De Vivo P, Del Gaudio A, Ciritella P, Puopolo M, Chiarotti F, Mastronardi E. Hypertonic saline solution: a safe alternative to mannitol $18 \%$ in neurosurgery .Minerva Anestesiol. 2001;67:603-11.

40. Mustafa I, Leverve XM. Metabolic and hemodynamic effects of hypertonic solutions: sodium-lactate versus sodium chloride infusion in postoperative patients. Shock. 2002;18:306-10.

41. Ferber J, Lechowicz-Glogowska E, Zeber J, Turek T, Durek G. [The effect of small doses of $7.5 \% \mathrm{NaCl}$ on brain bulk during elective craniotomies]Folia Med Cracov. 2001;42:153-62.

42. Rocha-E-Silva R, Caneo LF, Lourenco Filho DD, Jatene MB, BarberoMarcial M, Oliveira SA, et al. First use of hypertonic saline dextran in children: a study in safety and effectiveness for atrial septal defect surgery. Shock. 2003;20:427-30.

43. Junger WG, Coimbra R, Liu FC, Herdon-Remelius C, Junger W, Junger $\mathrm{H}$, et al. Hypertonic saline resuscitation: a tool to modulate immune function in trauma patients? Shock. 1997;8:235-41.

44. Rizoli SB, Rotstein OD, Parodo J, Phillips MJ, Kapus A. Hypertonic inhibition of exocytosis in neutrophils: central role for osmotic actin skeleton remodeling. Am J Physiol Cell Physiol. 2000;279:C619-33.

45. Ciesla DJ, Moore EE, Zallen G, Biffl WL, Silliman CC. Hypertonic saline attenuation of polymorphonuclear neutrophil cytotoxicity: timing is everything. J Trauma. 2000;48:388-95.

46. Pascual JL, Ferri LE, Seely AJ, Campisi G, Chaudhury P, Giannias B, et al. Hypertonic saline resuscitation of hemorrhagic shock diminishes neutrophil rolling and adherence to endothelium and reduces in vivo vascular leakage. Ann Surg. 2002;236:634-42.

47. Hampton MB, Chambers ST, Vissers MC, Winterbourn CC. Bacterial killing by neutrophils in hypertonic environments. J Infect Dis. 1994;169:839-46.

48. Rizoli SB, Kapus A, Fan J, Li YH, Marshall JC, Rotstein OD. Immunomodulatory effects of hypertonic resuscitation on the development of lung inflammation following hemorrhagic shock. J Immunol. 1998;161:6288-96.

49. Rosengren S, Henson PM, Worthen GS. Migration-associated volume changes in neutrophils facilitate the migratory process in vitro. Am J Physiol. 1994;267(6 Pt 1):C1623-32.

50. Rizoli SB, Rotstein OD, Sibbald WJ. The immunological effects of hypertonic saline. In: JL V, ed. 2002 Yearbook of intensive care and emergency medicine. Berlin: Spring-Verlag;2002:446-53.

51. Tollofsrud S, Tonnessen T, Skraastad O, Noddeland H. Hypertonic saline and dextran in normovolaemic and hypovolaemic healthy volunteers increases interstitial and intravascular fluid volumes. Acta Anaesthesiol Scand. 1998;42:145-53.

52. Velasco IT, Pontieri V, Rocha e Silva M Jr, Lopes OU. Hyperosmotic $\mathrm{NaCl}$ and severe hemorrhagic shock. Am J Physiol. 1980;239:H664-73.
53. Fujita T, Matsuda Y, Shibamoto T, Uematsu H, Sawano F, Koyama $\mathrm{S}$. Effect of hypertonic saline infusion on renal vascular resistance in anesthetized dogs. Jpn J Physiol. 1991;41:653-63.

54. Drummer C, Gerzer R, Heer M, Molz B, Bie P, Schlossberger M, et al. Effects of an acute saline infusion on fluid and electrolyte metabolism in humans. Am J Physiol. 1992;262(5 Pt 2):F744-54.

55. Pascual JMS, Watson JC, Runyon AE, Wade CE, Kramer GC. Resuscitation of intraoperative hypovolemia: A comparison of normal saline and hyperosmotic/hyperoncotic solution in swine. Crit Care Med 1992;20:200-10

56. Kien ND, Kramer GC. Cardiac performance following hypertonic saline. Braz J Med Biol Res. 1989;22:245-8.

57. Kramer GC. Hypertonic resuscitation: physiologic mechanisms and recommendations for trauma care. J Trauma. 2003;54(5 Suppl):S89-99.

58. Tollofsrud S, Kramer GC. Intra-operative use of hypertonic solutions In: JL V, ed. 2000 Yearbook of intensive care and emergency medicine. Berlin: Spring-Verlag;2000:476-85.

59. Kien ND, Kramer GC, White DA. Acute hypotension caused by rapid hypertonic saline infusion in anesthetized dogs. Anesth Analg. 1991;73:597-602

60. Mazzoni MC, Borgstrom P, Intaglietta M, Arfors KE.Capillary narrowing in hemorrhagic shock is rectified by hyperosmotic salinedextran reinfusion.Circ Shock. 1990;31:407-18

61. Nakayama S, Kramer GC, Carlsen RC, Holcroft JW. Infusion of very hypertonic saline to bled rats: membrane potentials and fluid shifts. J Surg Res. 1985;38:180-6.

62. Rocha e Silva M, Velasco IT, Nogueira da Silva RI, Oliveira MA, Negraes GA, Oliveira MA. Hyperosmotic sodium salts reverse severe hemorrhagic shock: other solutes do not. Am J Physiol. 1987;253(4 Pt 2):H751-62.

63. Contant CF, Valadka AB, Gopinath SP, Hannay HJ, Robertson CS. Adult respiratory distress syndrome: a complication of induced hypertension after severe head injury. J Neurosurg. 2001;95:560-8.

64. Tremblay LN, Rizoli SB, Brenneman FD. Advances in fluid resuscitation of hemorrhagic shock. Can J Surg. 2001;44:172-9.

65. Rhee P, Koustova E, Alam HB. Searching for the optimal resuscitation method: recommendations for the initial fluid resuscitation of combat casualties. J Trauma. 2003;54(5 Suppl):S52-62.

66. Nguyen TT, Zwischenberger JB, Watson WC, Traber DL, Prough DS, Herndon DN, et al. Hypertonic acetate dextran achieves high-flow-lowpressure resuscitation of hemorrhagic shock. J Trauma. 1995;38:602-

67. Zavrakidis N. Intravenous fluids for abdominal aortic surgery (Cochrane Review). The Cochrane Library, Issue 2, 2004. Chichester, UK: Jhon Wiley \& Sons, Ltd.

68. Sauaia A, Moore FA, Moore EE, Lezotte DC. Early risk factors for postinjury multiple organ failure. World J Surg. 1996;20:392-400.

69. Chaudry IH, Ayala A, Ertel W, Stephan RN. Hemorrhage and resuscitation: immunological aspects. Am J Physiol. 1990;259(4 Pt 2):R663-78

70. Norwood MG, Bown MJ, Lloyd G, Bell PR, Sayers RD. The clinical value of the systemic inflammatory response syndrome (SIRS) in abdominal aortic aneurysm repair. Eur J Vasc Endovasc Surg. 2004;27:292-8. 